\title{
Viability and Effects on Bacterial Proteins by Oral Rinses with Hypochlorous Acid as Active Ingredient
}

Diana Marcela Castillo ${ }^{1}$, Yormaris Castillo ${ }^{1}$, Nathaly Andrea Delgadillo', Yineth Neuta ${ }^{1}$, Johana Jola ${ }^{2}$, Justo Leonardo Calderón ${ }^{3}$, Gloria Inés Lafaurie ${ }^{1}$

\author{
'Basic Oral Research Unit-UIBO, \\ Dental School, Universidad El \\ Bosque, Bogotá, Colombia \\ ${ }^{2}$ Dental School, Universidad El \\ Bosque, Bogotá, Colombia \\ ${ }^{3}$ Aquilabs S.A., Bogotá, Colombia \\ Correspondence: Prof. Dr. Gloria \\ Inés Lafaurie, Carrera 7 B Bis \\ No. 132 - 11, Bogotá, 110121, \\ Colombia. Tel: +57-648-9000. \\ e-mail: institutouibo@gmail.com
}

\begin{abstract}
This study investigated the effect of hypochlorous acid $(\mathrm{HOCl})$ rinses and chlorhexidine $(\mathrm{CHX})$ on the bacterial viability of $S$. mutans, $A$. israelii, P. gingivalis, $A$. actinomycetemcomitans, $E$. corrodens, $C$. rectus, K. oxytoca, K. pneumoniae and $E$. cloacae. The percentage of live bacteria was tested by fluorescence method using Live/Dead kit ${ }^{\circledR}$ and BacLight (Molecular Probes ${ }^{\circledR}$ ) and compared between groups by the Kruskal-Wallis and U Mann-Whitney tests with Bonferroni correction ( $p$ value $<0.012$ ). The effect of $\mathrm{HOCl}$ and $\mathrm{CHX}$ on total proteins of $P$. gingivalis and S. mutans was determined by SDS-PAGE. CHX showed a higher efficacy than $\mathrm{HOCl}$ against $S$. mutans, $A$. israelii, E. corrodens and E. cloacae $(\mathrm{p}<0.001)$ while $\mathrm{HOCl}$ was more effective than $\mathrm{CHX}$ against $P$. gingivalis, $A$. actinomycetemcomitans, $C$. rectus and $K$. oxytoca $(\mathrm{p}=0.001)$. $\mathrm{CHX}$ and $\mathrm{HOCl}$ had similar efficacy against $K$. pneumoniae. Proteins of $P$. gingivalis and $S$. mutans were affected similarly by $\mathrm{HOCl}$ and $\mathrm{CHX} . \mathrm{HOCl}$ reduced the bacterial viability especially in periodontopathic bacteria, which may support its use in the control of subgingival biofilm in periodontal patients.
\end{abstract}

\author{
Key Words: hypochlorous acid, \\ chlorhexidine, bacterial viability, \\ proteins, Porphyromonas \\ gingivalis, Aggregatibacter \\ actinomycetemcomitans, \\ Streptococcus mutans.
}

\section{Introduction}

Dental plaque is the most studied biofilm and it is the most common form of bacterial growth in the oral cavity (1). Many substances with antimicrobial effects have been developed and evaluated for the control of dental biofilm and gingivitis (2). Chlorhexidine (CHX) has been extensively studied in the inhibition of dental plaque, gingivitis reduction and is widely used in full-mouth disinfection protocols (3). However, CHX does not seem to be more effective than an essential-oil mouthwash to reduce gingivitis in long-term studies and its main action is the reduction of dental plaque $(4,5)$.

There is a great interest in the development of new molecules with antimicrobial effect against oral microorganisms with a significant control of dental caries and periodontal disease. Hypochlorous acid ( $\mathrm{HOCl}$ ) is a non-antibiotic antimicrobial solution developed during the First World War by the dilution and acidification of sodium hypochlorite (Dakin solution) for the treatment of infected wounds (6). $\mathrm{HOCl}$ is part of a group of small molecules known as reactive oxygen species (ROS) synthesized by immune system cells during phagocytosis of antigens (7). The molecule has demonstrated a broad antimicrobial spectrum for the inhibition of multiple Gram positive and Gram negative microorganisms, without causing side effects such as irritation of the mucosa or extrinsic pigmentation on the tooth surface or restorations. $\mathrm{HOCl}$ also has an important anti-inflammatory and proliferative activity (8-10).
The purpose of this study was to evaluate the antimicrobial activity of hypochlorous acid rinses on oral bacteria (Gram positive and Gram negative) and study its effects on proteins of two of the major opportunistic and pathogenic oral microorganisms: Porphyromonas gingivalis and Streptococcus mutans.

\section{Material and Methods HOCI Preparation}

A special formulation of $\mathrm{HOCl}$ for oral health was developed according to formulations and technology patented by Aquilabs S.A. (US patent: US2009/0258083A1) (11). The solutions were obtained with a concentration of available chlorine as $\mathrm{HOCl}$ of $250 \mathrm{ppm}(0.025 \%)$ and 500 ppm (0.05\%) according to NTC 1847 with an ORP (oxide reduction potential) of 950-1100 MV and a conductivity of $25.3 \mathrm{ds} / \mathrm{m}$, at a density of $1.01 \mathrm{~g} / \mathrm{mL}$ at pH $5.8 \pm 0.2$. HOCl solution was subjected to an accelerated stability test to ensure a stable solution for more than 12 months before losing 10\% of its active ingredient.

\section{Antimicrobial Mechanisms}

The viability for Streptococcus mutans ATCC 25175, Actinomyces israelii ATCC 12012, Porphyromonas gingivalis ATCC 33277, Aggregatibacteractinomycetemcomitans ATCC 29523, Eikenella corrodens ATCC 23834, Campylobacter rectus ATCC 33238, Klebsiella oxytoca ATCC 43086, Klebsiella pneumoniae ATCC 700603, Enterobacter cloacae ATCC 13047 was tested by fluorescence method using Live/ 
Dead kit ${ }^{\circledR}$ and BacLight (Molecular Probes ${ }^{\circledR}$ ).

\section{Bacterial Culture and Inoculum Standardization}

ATTC strains of $P$. gingivalis, A. israelii, E. corrodens and C. rectus were grown in supplemented brucella agar $(0.3 \%$ Bacto agar, $0.2 \%$ yeast extract, $5 \%$ defibrinated sheep blood, $0.2 \%$ hemolyzed blood, $0.0005 \%$, hemin, $0.00005 \%$ and menadione) and incubated at $37{ }^{\circ} \mathrm{C}$ for 4 days in anaerobic conditions (Anaerogen, Oxoid, Hampshire, UK). A. actinomycetemcomitans was seeded in agar Dentaid 1 and incubated at $37{ }^{\circ} \mathrm{C}$ for $72 \mathrm{~h}$ with $5-10 \% \mathrm{CO}_{2}$. S. mutans was grown in blood agar (Blood Agar Base with 5\% sheep blood) and incubated at $37{ }^{\circ} \mathrm{C}$ for $24 \mathrm{~h}$ with $5-10 \% \mathrm{CO}_{2}$. K. oxytoca, K. pneumoniae and E. cloacae were plated on $\mathrm{BHI}$ agar (Brain Heart Infusion) and incubated for 24-48 $\mathrm{h}$ at $37^{\circ} \mathrm{C}$ in aerobic atmosphere. Subsequently, inocula were performed in $\mathrm{BHI}$ broth (Brain Heart Infusion) and were quantified by spectrophotometry for specific optical densities (OD) of $1 \times 10^{8}$ cells $/ \mathrm{mL}$ or higher according to Time Kill Assay protocol (12). After obtaining the expected OD base 10 , serial dilutions were plated on appropriate agar for each type of microorganism and incubated under the conditions referred above, to confirm count colony forming

\section{Bacterial Viability Test}

To evaluate the number of live and dead bacteria after exposure to different concentrations of $\mathrm{HOCl}$ and CHX $0.2 \%$, the inocula of all previously described bacteria were adjusted to a $1 \times 10^{8}$ bacteria $/ \mathrm{mL}$ concentration and cultured in BHI broth. $230 \mu \mathrm{L}$ of each bacteria in culture were exposed by for $30 \mathrm{~s}$ to $700 \mu \mathrm{L}$ of $\mathrm{HOCl}$ at $250 \mathrm{ppm}$ and $500 \mathrm{ppm}$ concentrations at $\mathrm{pH}=5.8$. Reactions were neutralized with $70 \mu \mathrm{L}$ of sodium thiosulfate $0.10 \mathrm{~N}$ and the mixture $(\mathrm{HOCl}+$ bacteria + neutralizer), and centrifuged at 14,000 rpm during 5 $\min$. The pellet was re-suspended in 50 $\mu \mathrm{L}$ of the supernatant and the excess was discarded. $0.15 \mu \mathrm{L}$ of the viability mixture (Live/Dead ${ }^{\circledR}$ BacLight Bacterial Viability) was added to the $50 \mu \mathrm{L}$ pellet. The mixture contains two dyes: SYTO 9 $3.34 \mathrm{mM}$ and propidium iodide $20 \mathrm{mM}$. Samples were incubated in low-light conditions for $15 \mathrm{~min}$. The dyes were used to differentiate the bacteria with intact membrane (green fluorescence) from the bacteria with abnormal membrane (red fluorescence). Positive control with $\mathrm{CHX} 0.2 \%$ and negative control without treatment were used in the same experimental conditions. The laminas were preincubated with $2 \mu \mathrm{L}$ of formaldehyde at $2 \%$, in order to immobilize the bacteria. Images were observed in a fluorescence microscope (Axio-Imager A2; Zeiss, Jena, Germany) in greater magnification and digitized using the AxioVision LE 4.8 software (Zeiss Microscopy). Quantification was determined by the number of pixels for live and dead bacteria using the ImageJ software (National Institutes of Health, Bethesda, MD, USA) and data were expressed as percent of viability.

\section{Evaluation of the Protein Integrity}

P. gingivalis ATCC 33277 and S. mutans ATCC 25175 were cultured as described above. A suspension of each bacterium was made in $\mathrm{BH}$ broth and standardized to a concentration of $1 \times 10^{8}$ bacteria/mL and adjusted spectrophotometrically as above described. Bacterial suspensions were exposed to $\mathrm{HOCl}$ at $250 \mathrm{ppm}$ and 500 $\mathrm{ppm}$ at $\mathrm{pH}=5.8$. $\mathrm{CHX} 0.2 \%$ was used as positive control and untreated inoculum as negative control. The cell pellet was washed in PBS (Phosphate Buffer Saline) and re-suspended in $2 \mathrm{~mL}$ of lysis buffer ( $50 \mathrm{mM}$ Tris pH=7.5, $50 \mathrm{mM} \mathrm{NaCl}, 5 \%$ glycerol). For $P$. gingivalis, bacterial inhibitor and proteinase $\mathrm{K}(10 \mathrm{mg} / \mathrm{mL})$ was added and incubated for $15 \mathrm{~min}$ at 65 ${ }^{\circ} \mathrm{C}$. For S. mutans, buffer plus bacterial protease inhibitor and $20 \mathrm{mg} / \mathrm{mL}$ of lysozyme was added and incubated at 37 ${ }^{\circ} \mathrm{C}$ overnight. The samples ere sonicated on ice in a Sonics Vibra-Cell VCX 130 ultrasonic processor (Sonics \& Materials, Inc. Newtown, CT, USA) with 40\% amplitude, totalizing 7 cycles $\left(30 \mathrm{~s}\right.$ on, $15 \mathrm{~s}$ off). The extracts were stored at $-20^{\circ} \mathrm{C}$.

The protein concentration was determined using the bicinchoninic acid reagent (BCA) to quantify the outer membrane protein by a colorimetric method (13) and determining the concentration of the protein according to
Table 1. Standardized bacterial inoculum

\begin{tabular}{lccc}
\hline Bacteria & Wavelength & OD \pm 0.02 & $\begin{array}{c}\text { Bacteria/mL (CFU) } \\
\text { mean } \pm \text { SD x 10 }\end{array}$ \\
\hline Streptococcus mutans ATCC 25175 & $580 \mathrm{~nm}$ & 0.570 & $1.5 \pm 0.7$ \\
Actinomyces israelii ATCC 12012 & $600 \mathrm{~nm}$ & 1.000 & $1 \pm 0$ \\
Klebsiella oxytoca ATCC 43086 & $580 \mathrm{~nm}$ & 0.700 & $1.66 \pm 0.5$ \\
Klebsiella pneumoniae ATCC 700603 & $580 \mathrm{~nm}$ & 1.000 & $1.66 \pm 1.5$ \\
Enterobacter cloacae ATCC 13047 & $580 \mathrm{~nm}$ & 0.980 & $1 \pm 0.5$ \\
A. actinomycetemcomitans ATCC 29523 & $480 \mathrm{~nm}$ & 1.700 & $2.33 \pm 1.5$ \\
Porphyromonas gingivalis ATCC 33277 & $620 \mathrm{~nm}$ & 0.900 & $1.66 \pm 1.1$ \\
Eikenella corrodens ATCC 23834 & $620 \mathrm{~nm}$ & 1.500 & $1.5 \pm 0.7$ \\
Campylobacter rectus ATCC 33238 & $620 \mathrm{~nm}$ & 1.000 & $1.33 \pm 0.5$ \\
\hline
\end{tabular}


the manufacturer's instructions (Thermo Specific).

The integrity of the proteins was evaluated using electrophoresis in polyacrylamide gel in 10\% SDS (sodium dodecyl sulfate) and a standard pattern of known molecular weight was used to determine the molecular weights of the different bacterial proteins. Separating gels (12\%
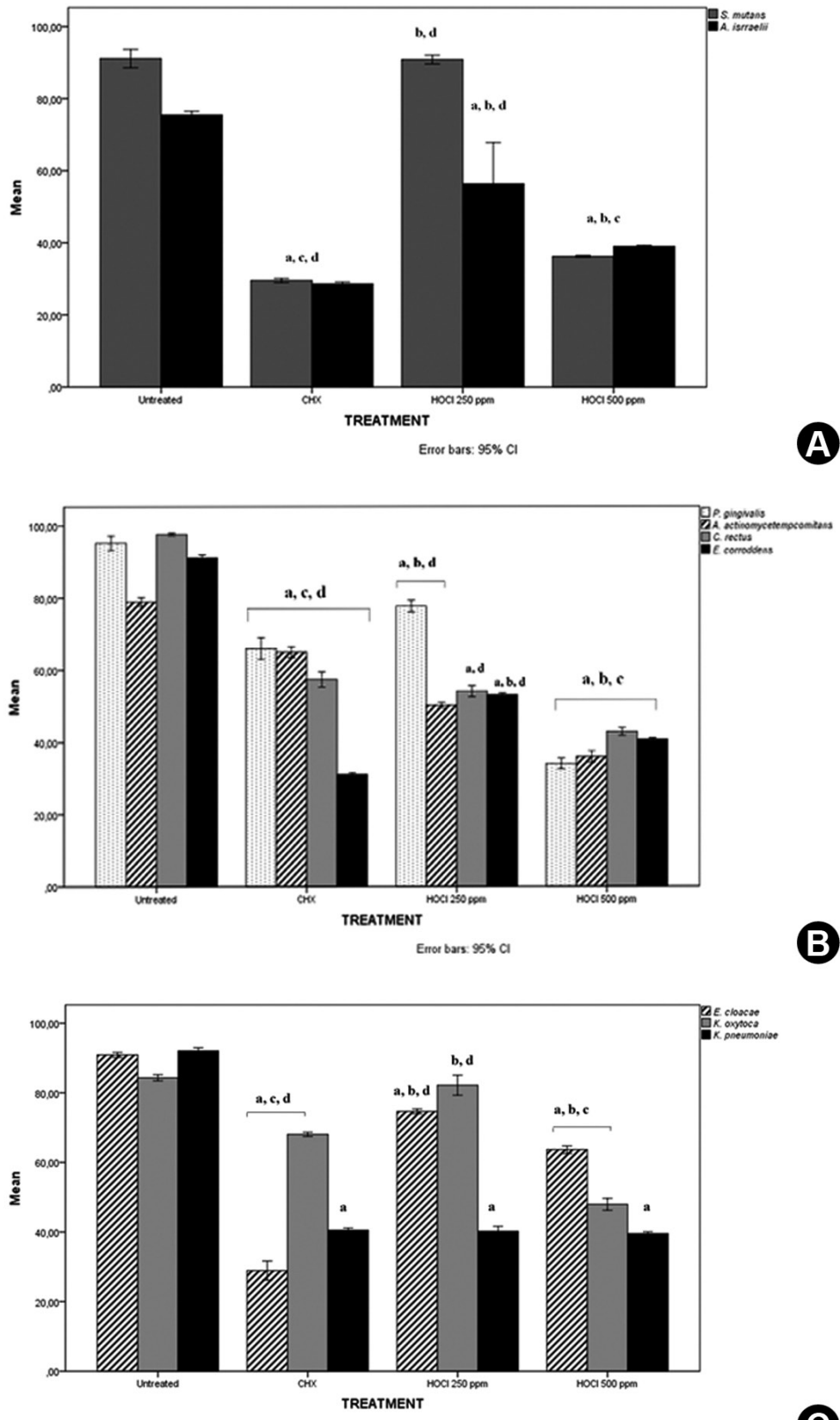

Error bars: $95 \% \mathrm{Cl}$

Figure 1. Percentage of bacterial viability after 30 seconds treatment with $\mathrm{CHX}, \mathrm{HOCl}$ de $250 \mathrm{ppm}$ and $500 \mathrm{ppm}$. A: Gram positive bacteria: S. mutans ATCC 25175 and A. israelii ATCC 12012. B. Gram negative bacteria associated to periodontal disease: P. gingivalis ATCC 33277, A. actinomycetemcomitans ATCC 29523, C. rectus ATCC 33238 and E. corrodens ATCC 23834. C. Enteric rods: E. cloacae ATCC 13047, K. oxytoca ATCC 43086 and K. pneumoniae ATCC 700603. p-values come from t-test or Kruskal Wallis y U Mann-Whitney $(p \leq 0,012)$. a: $p$-value for differences with untreated; $b$ : $p$-value for differences with chlorhexidine; c: $p$-value for differences with HOCl 250 ppm; d: p-value for differences with $\mathrm{HOCl} 500$ ppm.
(A)

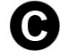

acrylamide/bisacrylamide) were used and the samples diluted in Laemmli buffer in each well with the same protein concentration $(20 \mu \mathrm{g} / \mu \mathrm{L})$ to evaluate the differences in the electrophoretic profile of the bacteria treated with the different $\mathrm{HOCl}$ concentrations. A run buffer with $3 \%$ Tris base, $14 \%$ glycine, $1 \% \mathrm{SDS}, \mathrm{pH}=8.3$ was used and the gels were run for 80 min at $100 \mathrm{~V}$. Past the runtime each gel was stained using Silver Stain Kit Pierce ${ }^{\circledR}$ (Thermo Fisher Scientific, Inc., Waltham, MA, USA.), following the manufacturer's recommendations.

\section{Statistical Analysis}

The average of live bacteria for each experiment was calculated as percentage. The viability reduction was calculated as the difference of living bacteria between the untreated controls per experiment. Descriptive analysis of the means and standard deviations were made. Viability percentages between different rinses were compared through the Kruskal Wallis and U Mann-Whitney test with Bonferroni correction. A $p$-value of $<0.012$ was established for differences between groups.

\section{Results Inoculum Standardization}

Table 1 shows the average and standard deviation of CFU counts for reference strains used in the standardization phase of the bacterial inoculum, required to perform the tests at a concentration of $1 \times 10^{8}$ bacteria/mL or higher according to the recommendations of the ASTM E2315-03 for the Time Kill Method for antimicrobial agents (12).

\section{Bacterial Viability Assessment}

Viability percentages for Gram positive observed in Fig. 1A. The viability of S. mutans and $A$. israelii was significantly affected by $\mathrm{CHX}$ to $0.2 \%$ and $\mathrm{HOCl}$ at $500 \mathrm{ppm}$ when compared with the untreated control and with $\mathrm{HOCl}$ at $250 \mathrm{ppm}(\mathrm{p}=0.001)$. However, $0.2 \% \mathrm{CHX}$ showed a higher efficacy against these microorganisms when compared with all groups $(p<0.001)$. HOCl 250 ppm showed greater effect than the control for $A$. israelii $(p=0.0032)$, but did not show differences against $S$. mutans ( $p=0.64$ ) (Fig. 1). 500 ppm $\mathrm{HOCl}$ showed to be the most effective substance reducing the viability of Gram 
negative organisms associated with periodontal disease. $P$. gingivalis, $A$. actinomycetemcomitans and $C$. rectus showed significant differences for $\mathrm{HOCl}$ at $500 \mathrm{ppm}$ in all evaluated groups including $\mathrm{CHX} 0.2 \%(\mathrm{p}=0.001)$. CHX $0.2 \%$ showed better effectiveness in $E$. corrodens compared to all groups ( $p<0.001$ ). However, $\mathrm{HOCl}$ to $250 \mathrm{ppm}$ and 500 ppm were more effective than the control group for this microorganism $(p<0.001)$ Figure $1 \mathrm{~B}$. Viability of $P$. gingivalis after treatments is observed in Figure 2.

The enteric rods commonly found as contaminants in samples of saliva and subgingival plaque were affected by the solutions in study. K. pneumoniae showed a similar reduction to $0.2 \% \mathrm{CHX}$ and the two concentrations of $\mathrm{HOCl}$ $(p>0.05)$. K. oxytoca showed reduced viability for $\mathrm{HOCl} 500$ ppm for all evaluated groups $(\mathrm{p}<0.001)$. CHX $0.2 \%$ showed a better efficacy against $K$. oxytoca than $\mathrm{HOCl}$ at 250 $\mathrm{ppm}$ and the control group $(\mathrm{p}<0.001)$. E. cloacae showed a significant decrease in bacterial viability for $0.2 \% \mathrm{CHX}$ compared to all evaluated groups (Fig. 1C).

\section{Evaluation of the Protein Integrity}

After the treatment with $\mathrm{HOCl}$ at $500 \mathrm{ppm}, 250 \mathrm{ppm}$ and $\mathrm{CHX}$ there was an important change in the banding pattern in bacterial proteins for the reference strains of $P$. gingivalis and S. mutans. A disappearance of a large part of the bands is observable compared to the untreated control.

For $P$. gingivalis some of the low molecular weight proteins are conserved, on the other side the high molecular weight proteins lose their sharpness as if the proteins concentrations decreased after the treatment with $\mathrm{HOCl}$. After treatment with $\mathrm{CHX}$ thin proteic profile is observed. However the protein concentration seems to be affected, suggesting some kind of protein alterations, but less than with $\mathrm{HOCl}$. In $\mathrm{S}$ mutans is more evident the disappearance of the bands with high molecular weight and a band of approximately $28 \mathrm{kD}$ is conserved for all treatments. A band of $70 \mathrm{kD}$ for the $\mathrm{HOCl}$ at $250 \mathrm{ppm}$ is conserved but in minor concentration. All experiments were made by triplicate and presented the same behavior (Fig. 3).

\section{Discussion}

There is an agreement on the effect of various antiplaque substances to reduce gingivitis in long term studies (4). However, the effective reduction of plaque and gingivitis in the short term is still under study. Chlorhexidine remains as the gold standard as antiplaque agent in short and long term effect (5). Despite their wide use, some adverse effects have discouraged its use, as tooth discoloration as it is easily
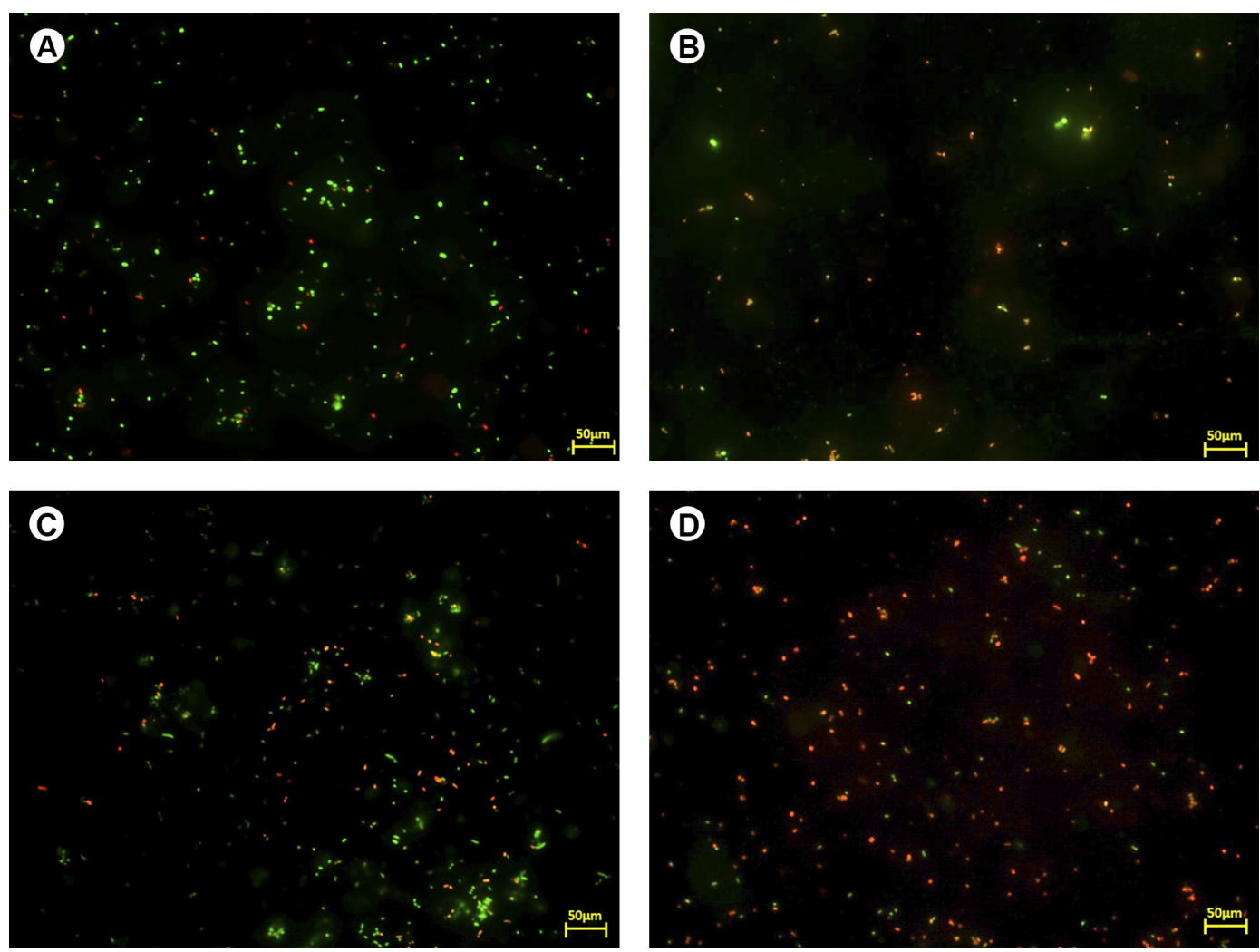

Figure 2. Bacterial viability of $P$. gingivalis ATCC 33277. Green fluorescent bacteria are alive and red fluorescing bacteria are dead. A: untreated; B: 0.2\% chlorhexidine; C: $\mathrm{HOCl} 250$ ppm, pH 5.8 and D: $\mathrm{HOCl} 500$ ppm, pH 5.8. 
mixed with the dietary chromogens, weak microbicidal activity at low concentrations and at high concentrations may produce dermatitis and desquamation of oral mucosa as well as delay in healing $(14,15)$.

Hypochlorous acid rinses are proposed for plaque control and as a wound healing agent for its use in oral health, due to its low toxicity, high antimicrobial efficacy, anti-inflammatory effect, induction to cell proliferation and its background as a topical solution in the antisepsis of wounds in clinical medicine (16). $\mathrm{HOCl}$ has also the ability to oxidize the amino acid taurine and induce the formation of chlorine-taurine (TauCl) which has broad spectrum antimicrobial activity. The $\mathrm{TauCl}$ has a significant protective effect on tissues because it can inhibit the production of inflammatory mediators and thereby contribute to the processes of tissue protection (10).

In this study, $\mathrm{HOCl}$ showed a significant effect on Gram positive bacteria but did not exceed the effect of chlorhexidine. Chlorhexidine has shown better effect on Gram positive microorganisms but less on Gram negative microorganisms $(17,18)$. The antimicrobial action of $\mathrm{HOCl}$ appears to be greater in Gram negative than in Gram positive possibly because Gram negative bacteria has sulfur and hem groups (rich in iron) in its membrane which causes an irreversible reaction $\mathrm{HOCl} /$ membrane proteins, producing structural damage, and altering cell permeability, affecting bacterial viability in Gram negative bacteria $(19,20)$. The $\mathrm{HOCl}$ oxidizes and/or chlorinates endotoxins and exotoxins such as lipopolysaccharides and gingipains as Rgp and Kgp neutralizing their action. In Gram positive bacteria $\mathrm{HOCl}$ oxidizes glycine residues present in the peptidoglycan, on the other hand chlorination reactions in this group of microorganisms differs in the action on the target (21).

Different authors have controversial uses of microbiological culture methods to evaluate the efficacy of antimicrobials. The bacterial viability assessment with specific methods such as fluorochromes or epifluorescence has been proposed for evaluation of antimicrobials (22). In the present study a method of epifluorescence was used for the evaluation of the bacterial viability similar to the reported by other studies that have evaluated the substantivity of antiplaque substances $(23,24)$.

Proteins of $P$. gingivalis and $S$. mutans were affected after $30 \mathrm{~s}$ of treatment with the test solutions. For $P$. gingivalis, after $\mathrm{HOCl}$ and $\mathrm{CHX}$ treatments it is observed a similar reduction of the protein concentrations in many bands when is compared with the untreated control. In $S$. mutans there is an elimination of almost all the proteins for the different treatments when compared with the untreated control. Cheung et al., in 2011 have shown changes in the proteic profile in Bacillus subtilis and E. coliafter treatment with $\mathrm{CHX}$, suggesting that the mechanism of action of $\mathrm{CHX}$ is related with an alteration of lipidic stability of the cell membrane (25). It is not clear which is the action of $\mathrm{HOCl}$ on bacteria, however oxidation and chlorination of amino groups in some functional and structural proteins in Gram positive and Gram negative bacteria is suggested (7). In further it is important to identify the proteins affected by $\mathrm{HOCl}$ action and thus explain how this antimicrobial molecule affects the bacterial viability and why in some Gram negative bacteria as E. cloacae does not have an important reduction in the viability.

The formulation of $\mathrm{HOCl}$ has been stabilized in Colombia and patented as an substance with antimicrobial effects

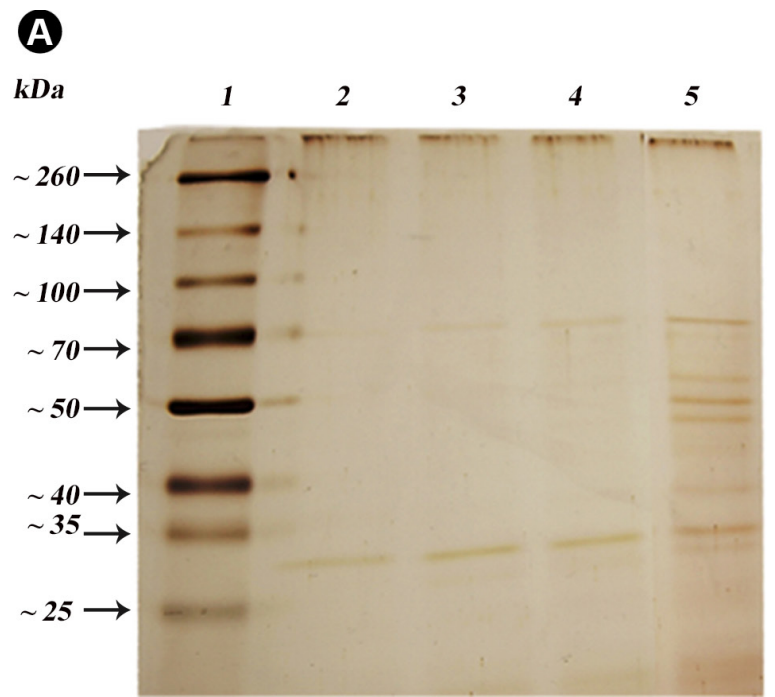

B

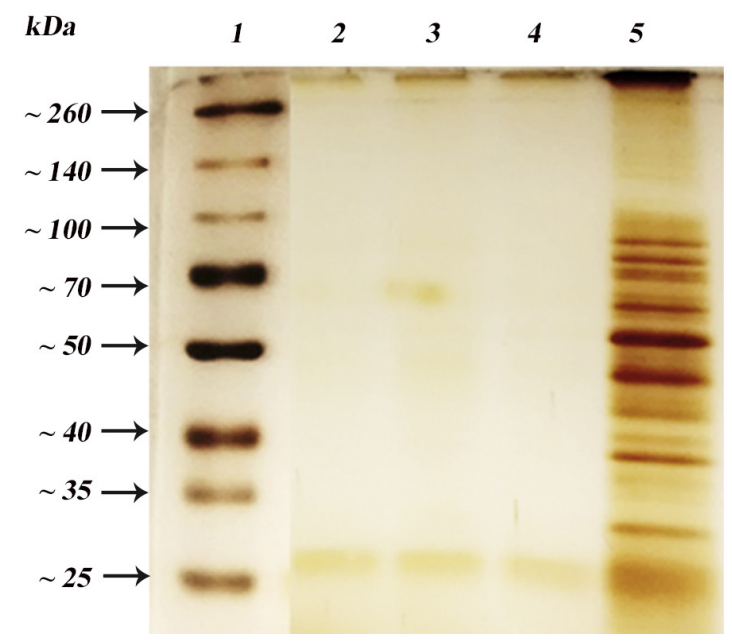

Figure 3. Total protein electrophoretic profile of P. gingivalis ATCC 33277 (A) and S. mutans ATCC 25175 (B). Lanes: 1 molecular weight marker; 2. Treatment with $\mathrm{HOCl} 250 \mathrm{ppm}$; 3. Treatment with $\mathrm{HOCl} 500 \mathrm{ppm}$; 4. Treatment with CHX; 5. Without treatment. 
for medical applications such as the treatment of chronic and non-healing wounds (11). Findings of this study could support future research of $\mathrm{HOCl}$ as antimicrobial and antiplaque agent in dentistry.

$\mathrm{HOCl}$ showed better effects on bacterial viability than $\mathrm{CHX}$ in Gram negative microorganism specially in $P$. gingivalis, $A$. actinomycetemcomitans and $C$. rectus. $\mathrm{HOCl}$ could have a significant effect on periodontophatic bacteria that could colonize and aggregates as dental biofilm.

\section{Resumo}

Este estudo investigou o efeito de enxaguantes à base de ácido hipocloroso ( $\mathrm{HOCl}$ ) e clorexidina (CHX) sobre a viabilidade bacteriana de S. mutans, A. israelii, P. gingivalis, A. actinomycetemcomitans, E. corrodens, C. rectus, $K$. oxytoca, K. pneumoniae e E. cloacae. 0 percentual de bactérias sobreviventes foi testado pelo método de fluorescência utilizando Live/ Dead kit ${ }^{\circledR}$ e BacLight (Molecular Probes ${ }^{\circledR}$ ), fazendo comparação entre os grupos com os testes de Kruskal-Wallis e U Mann-Whitney e correção de Bonferroni $(\mathrm{p}<0,012)$. 0 efeito de $\mathrm{HOCl}$ e CHX sobre P. gingivalise $S$. mutans foi determinado por SDS-PAGE. $0 \mathrm{CHX}$ mostrou eficácia superior ao $\mathrm{HOCl}$ contra S. mutans, A. israelii, E. corrodens e $E$. cloacae $(p<0,001)$, ao passo que $P$. gingivalis, $A$. actinomycetemcomitans, $C$. rectus e $K$. oxytoca foram melhores que o $\mathrm{CHX}$ para o $\mathrm{HOCl}(\mathrm{p}=0,001)$. 0 K. pneumoniae teve efeito similar para o $\mathrm{CHX}$ e para o $\mathrm{HOCl}$. As proteinas de $P$. gingivalis e S. mutans foram afetadas de modo semelhante por $\mathrm{CHX}$ e $\mathrm{HOCl}$. $\mathrm{HOCl}$ reduziu a viabilidade bacterial, especialmente nas bactérias periodontopáticas, o que pode recomendar o uso no controle do biofilme subgingival em pacientes periodentais.

\section{Acknowledgements}

The authors thanks to the Colombian Department for Science, Technology and Innovation (COLCIENCIAS) as the sponsor of this project through the Grant No 130850227678 To Dr. Marcela Buitrago for it assistance in the development of the SDS-Page.

\section{References}

1. Palmer RJ. Oral bacterial biofilms - history in progress. Microbiology 2009;155: 2113-2114.

2. Teles RP, Teles FR. Antimicrobial agents used in the control of periodontal biofilms: effective adjuncts to mechanical plaque control? Braz Oral Res 2009;23Suppl1:39-48.

3. Van Strydonck DA, Slot DE, Van der Velden U, Van der Weijden F. Effect of a chlorhexidine mouth rinse on plaque, gingival inflammation and staining in gingivitis patients: a systematic review. J. Clin. Periodontol 2012;39:1042-1055.

4. Van Leeuwen MP, Slot DE, Van der Weijden GA. Essential oils compared to chlorhexidine with respect to plaque and parameters of gingival inflammation: a systematic review. J. Periodontol 2011;82:174-194.

5. Neely AL. Essential oil mouth wash (EOMW) may be equivalent to chlorhexidine ( $\mathrm{CHX}$ ) for long-term control of gingival inflammation but CHX appears to perform better than EOMW in plaque control. J Evid Based Dent Pract 2012;12:69-72.

6. Levine JM. Dakin's solution: past, present, and future. Adv Skin Wound Care 2013;26:410-414.

7. Green JN, Kettle AJ, Winterbourn CC. Protein chlorination in neutrophil phagosomes and correlation with bacterial killing. Free Radic Biol Med 2014;77:49-56.
8. Wang L, Bassiri M, Najafi R, Najafi $K$, Yang J, Khosrovi B, et al.. Hypochlorous acid as a potential wound care agent: Part I. Stabilized hypochlorous acid: a component of the inorganic armamentarium of innate immunity. J Burns Wounds 2007;11;6:e5.

9. Fu X, Kassim SY, Parks WC, Heinecke JW. Hypochlorous acid generated by myeloperoxidase modifies adjacent tryptophan and glycine residues in the catalytic domain of matrix metalloproteinase-7 (matrilysin): an oxidative mechanism for restraining proteolytic activity during inflammation. J Biol Chem 2003;278:28403-28409.

10. Kim C, Cha YN. Taurine chloramine produced from taurine under inflammation provides anti-inflammatory and cytoprotective effects. Amino Acids 2014;46:89-100.

11. Method of producing and applications of composition of hypochlorous acid. Available in: http://www.wipo.int/portal/en/.

12. Standard Guide for Assessment of Antimicrobial Activity Using a TimeKill Procedure 1. International Standards Worldwide 2004;E:2315-03.

13. Smith PK, Krohn RI, Hermanson G, Mallia A, Gartner FH, Provenzano M, et al.. Measurement of protein using bicinchoninic acid. Anal Biochem 1985; 150:76-85

14. Jones CG. Chlorhexidine: is it still the gold standard? Periodontol 2000 1997;15:55-62.

15. Graziani F, Gabriele M, D'Aiuto F, Suvan J, Tonelli M, Cei S. Dental plaque, gingival inflammation and tooth -discolouration with different commercial formulations of $0.2 \%$ chlorhexidine rinse: a double-blind randomised controlled clinical trial. Oral Health Prev Dent 2015;13:101-111.

16. Selkon J,B, Cherry GW, Wilson JM, Hughes M A. Evaluation of hypochlorous acid washes in the treatment of chronic venous leg ulcers. J Wound Care 2006;15:33-37.

17. De Rossi A, Ferreira DC, da Silva RA, de Queiroz AM, da Silva LA, NelsonFilho $P$. Antimicrobial activity of toothpastes containing natural extracts, chlorhexidine or triclosan. Braz Dent J 2014;25:186-190.

18. Ferraz CC, Gomes BP, Zaia AA, Teixeira FB, Souza-Filho FJ. Comparative study of the antimicrobial efficacy of chlorhexidine gel, chlorhexidine solution and sodium hypochlorite as endodontic irrigants. Braz Dent J 2007;18:294-298.

19. Rosen H, Klebanoff S. Oxidation of Escherichia coli iron centers by the myeloperoxidase-mediated microbicidal system. J Biol Chem 1982;257:13731-13735.

20. Mckenna SM, Davies KJ. The inhibition of bacterial growth by hypochlorous acid. Possible role in the bactericidal activity of phagocytes. Biochem J 1988;254:685-692.

21. Chong-Hou S, Hsein-Kun L. The role of hypochlorous acid as one of the reactive oxygen species in periodontal disease. J Dent Sci 2009;4:45-54.

22. Berney $M$, Hammes $F$, Bosshard F, Weilenmann HU, Egli T. Assessment and interpretation of bacterial viability by using the LIVE /DEAD Baclight Kit in combination with flow cytometry. Appl Environ Microbiol 2007;73:3283-3290.

23. Garcia-Caballero L, Carmona IT, González MC, Posse JL, Taboada JL, Dios PD. Evaluation of the substantivity in saliva of different forms of application of chlorhexidine. Quintessence Int 2009;40:141-144.

24. Herrera D, Roldan S, Santacruz I, Santos S, Masdevall M, Sanz M: Differences in antimicrobial activity of four commercial $0.12 \%$ chlorhexidine mouth rinse formulations: an in vitro contact test and salivary bacterial counts study. J Clin Periodontol 2003;30:307-314.

25. Cheung HY1, Wong MM, Cheung SH, Liang LY, Lam YW, Chiu SK. Differential actions of chlorhexidine on the cell wall of Bacillus subtilis and Escherichia coli. PLoS One 2012;7:e36659.

Received December 13, 2014 Accepted June 23, 2015 